\author{
Marquette University \\ e-Publications@Marquette
}

$10-2020$

\title{
Distance Dependent Energy Transfer Dynamics from a Molecular Donor to a Zeolitic Imidazolate Framework Acceptor
}

Wenhui Hu

Marquette University

Fan Yang

San Diego State University

Nick Pietraszak

Marquette University

Jing $\mathrm{Gu}$

San Diego State University

Jier Huang

Marquette University, jier.huang@marquette.edu

Follow this and additional works at: https://epublications.marquette.edu/chem_fac

Part of the Chemistry Commons

\section{Recommended Citation}

Hu, Wenhui; Yang, Fan; Pietraszak, Nick; Gu, Jing; and Huang, Jier, "Distance Dependent Energy Transfer Dynamics from a Molecular Donor to a Zeolitic Imidazolate Framework Acceptor" (2020). Chemistry Faculty Research and Publications. 1031.

https://epublications.marquette.edu/chem_fac/1031 
Marquette University

e-Publications@Marquette

\title{
Chemistry Faculty Research and Publications/College of Arts and Sciences
}

This paper is NOT THE PUBLISHED VERSION.

Access the published version via the link in the citation below.

Physical Chemistry Chemical Physics, Vol. 22, No. 44 (October 2020): 25445-25449. DOI. This article is (C) Royal Society of Chemistry and permission has been granted for this version to appear in ePublications@Marquette. Royal Society of Chemistry does not grant permission for this article to be further copied/distributed or hosted elsewhere without the express permission from Royal Society of Chemistry.

\section{Distance Dependent Energy Transfer Dynamics from a Molecular Donor to a Zeolitic Imidazolate Framework Acceptor}

\author{
Wenhui Hu \\ Department of Chemistry, Marquette University, Milwaukee, Wisconsin \\ Fan Yang \\ Department of Chemistry and Biochemistry, San Diego State University, San Diego, California \\ Nick Pietraszak \\ Department of Chemistry, Marquette University, Milwaukee, Wisconsin \\ Jing $\mathrm{Gu}$ \\ Department of Chemistry and Biochemistry, San Diego State University, San Diego, California \\ Jier Huang \\ Department of Chemistry, Marquette University, Milwaukee, Wisconsin
}




\section{Abstract}

Zeolitic Imidazolate frameworks (ZIFs) have been demonstrated as promising light harvesting and photocatalytic materials for solar energy conversion. To facilitate their application in photocatalysis, it is essential to develop a fundamental understanding of their light absorption properties and energy transfer dynamics. In this work, we report distance-dependent energy transfer dynamics from a molecular photosensitizer (RuN3) to ZIF-67, where the distance between RuN3 and ZIF-67 is finely tuned by depositing an ultrathin $\mathrm{Al}_{2} \mathrm{O}_{3}$ layer on the $\mathrm{ZIF}-67$ surface using an atomic layer deposition (ALD) method. We show that energy transfer time decreases with increasing distance between RuN3 and ZIF-67 and the Förster radius is estimated to be $14.4 \mathrm{~nm}$.

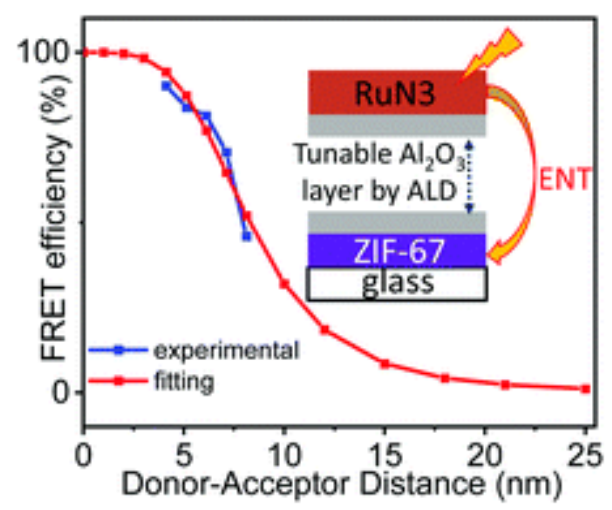

\section{Introduction}

Zeolitic imidazolate frameworks (ZIFs), a subclass of metal organic frameworks (MOFs), are composed of $\mathrm{Zn}^{2+}$ or $\mathrm{Co}^{2+}$ nodes tetrahedrally coordinated with imidazole-based organic linkers. ${ }^{1-5}$ Owing to their ordered porous structure and large surface area, ZIFs have emerged as new materials for gas storage and separation, ${ }^{6-9}$ chemical sensing, ${ }^{10,11}$ and catalysis. ${ }^{12-14}$ Driven by the demand for renewable energy and environmental concerns, recent interests have extended their application in photocatalysis with a number of reports having demonstrated their capability as photocatalytic materials. ${ }^{15-19}$ However, in the majority of these systems, ZIFs were either used as hosts for reaction substrates/catalytic active species or templates to synthesize porous hybrid materials through an annealing process. ${ }^{20-24}$ In contrast, our recent studies showed that ZIFs based on Co nodes and 2-methyl imidazolate ligand (ZIF-67) not only possess broad absorption in the UV-visible-near IR region but also exhibit a long-lived excited state (ES), where the porous framework of ZIF-67 plays a central role in the formation of the long-lived ES. ${ }^{25,26} \mathrm{~A}$ further study then showed that the electron in this ES state can be extracted through interfacial electron transfer (ET) from excited ZIF-67 to methylene blue, which largely demonstrates the promise of using ZIFs as intrinsic light harvesting and charge separation materials for solar energy conversion. ${ }^{27}$

While ZIF-67 has broad absorption in both the visible and near IR region, the extinction coefficients of these spectral transitions resulting from dipole forbidden $d-d$ transitions of Co nodes are quite low ( 100-1000 mol $\left.\mathrm{L}^{-1} \mathrm{~cm}^{-1}\right) .{ }^{28}$ In response to this challenge, we encapsulated molecular (RuN3) ${ }^{29}$ and semiconductor $(\mathrm{CdS})^{30}$ photosensitizers (PS), which have absorption in the visible region that compensates the absorption of ZIF-67 and have much larger extinction coefficient, into ZIF-67. We showed that both systems can strengthen the light harvesting ability of ZIF-67 as efficient energy transfer (ENT) can occur from the guest PSs to ZIF-67. These results demonstrate that encapsulating a guest unit chromophore that can relay energy to ZIFs through ENT is a promising approach to enhance the light harvesting ability of ZIFs. A natural question that follows these ENT studies is to unravel the key factors that control the dynamics of ENT. It has been shown previously that ENT efficiency is largely dependent on the distance between the donor and acceptor. ${ }^{31-38}$ In this work, we report the impact of distance between RuN3 and ZIF-67 on the ENT dynamics in the RuN3/ZIF-67 hybrid. The distance 
between RuN3 and ZIF-67 is controlled by tuning the thickness of the $\mathrm{Al}_{2} \mathrm{O}_{3}$ layer from $3 \mathrm{~nm}$ to $8.5 \mathrm{~nm}$, which is deposited on the surface of the ZIF-67 film before sensitization of RuN3 using atomic layer deposition (ALD). We show that the ENT efficiency decreases with increasing thickness of $\mathrm{Al}_{2} \mathrm{O}_{3}$ between $\mathrm{RuN3}$ and $\mathrm{ZIF-67}$, where the theoretical Förster radius estimated according to the reported point to plane resonance energy transfer under

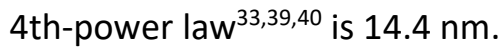

\section{Results and discussion}

The schematic representation of the synthesis of RuN3/ $\mathrm{Al}_{2} \mathrm{O}_{3} / \mathrm{ZIF}-67$ hybrid films is illustrated in Scheme 1 (see details in $\mathrm{ESI}+$ ). In the first step, a glass slide pre-treated with Piranha solution was immersed into the mixture of $\mathrm{Co}\left(\mathrm{NO}_{3}\right)_{2} \cdot 6 \mathrm{H}_{2} \mathrm{O}$ and 2-methylimidazole $(2 \mathrm{mlm})$. After about $1 \mathrm{~h}$, transparent and continuous $\mathrm{ZIF}-67$ film was formed on both sides of the glass slide (step I). ${ }^{25,29} \mathrm{ZIF}-67$ crystals on one side of the film are scratched off to make a single-side $\mathrm{ZIF}-67$ film. The $\mathrm{Al}_{2} \mathrm{O}_{3}$ layer with different thickness was then deposited on the surface of ZIF67 film using ALD (step II). At a temperature of $100-200{ }^{\circ} \mathrm{C}$, the deposition of $\mathrm{Al}_{2} \mathrm{O}_{3}$ usually has a stable growth rate of $0.1-0.11 \mathrm{~nm}$ per cycle on non-porous substrates. ${ }^{41-43}$ However, as demonstrated using the transmission electron microscopy (TEM) images, a much thicker layer of $\mathrm{Al}_{2} \mathrm{O}_{3}$ was identified (Fig. S1, ESI + ). This can be explained by the nanoporous structure of $\mathrm{ZIF}-67$, where $\mathrm{Al}_{2} \mathrm{O}_{3}$ is not only deposited on the surface but also the subsurface in the nanostructure. As a result, alternatively depositing 10 to 40 cycles of trimethylaluminum and water at $120^{\circ} \mathrm{C}$ resulted in a $3 \mathrm{~nm}$ to $8.5 \mathrm{~nm} \mathrm{Al}{ }_{2} \mathrm{O}_{3}$ thin film on ZIF-67 (Table S1, ESI ${ }^{\dagger}$ ). After the deposition of $\mathrm{Al}_{2} \mathrm{O}_{3}$, the same amount of RuN3 in methanol solution was dropped onto the $\mathrm{Al}_{2} \mathrm{O}_{3} / \mathrm{ZIF}-67$ films to form $\mathrm{RuN} 3 / \mathrm{Al}_{2} \mathrm{O}_{3} / \mathrm{ZIF}-67$ hybrid films (step III).

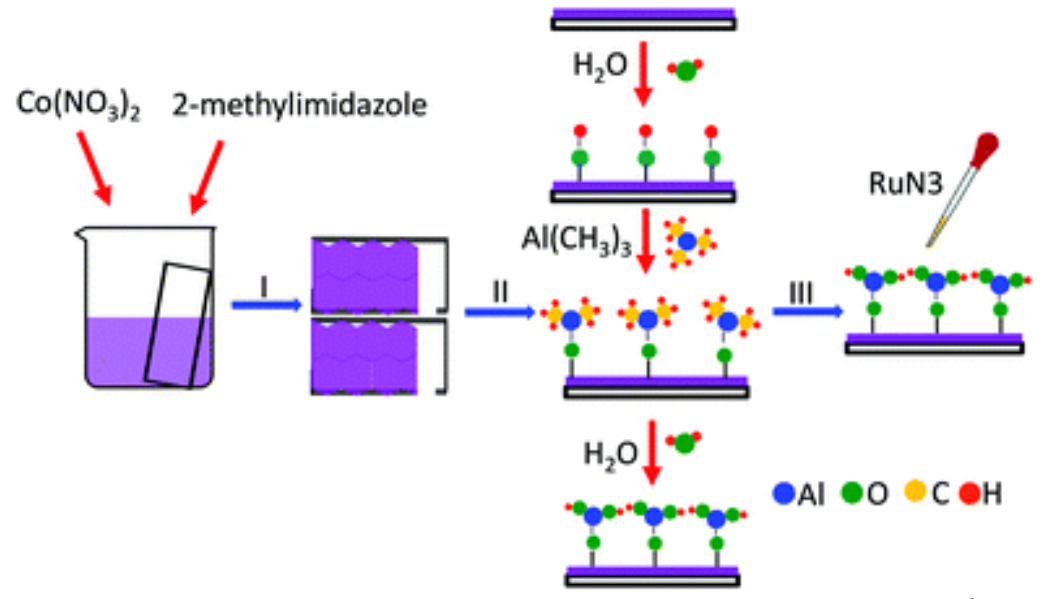

Scheme 1 Schematic representation of the synthesis of $\mathrm{RuN}_{3} / \mathrm{Al}_{2} \mathrm{O}_{3} / \mathrm{ZIF}-67$ thin film.

Fig. 1 a shows the XRD patterns of blank glass slides, $\mathrm{Al}_{2} \mathrm{O}_{3}$ on glass slides, $\mathrm{ZIF}-67$ on glass slides, $\mathrm{Al}_{2} \mathrm{O}_{3}(8.5$ $\mathrm{nm}) / \mathrm{ZIF}-67$, and $\mathrm{RuN3} / \mathrm{Al}_{2} \mathrm{O}_{3}(8.5 \mathrm{~nm}) / \mathrm{ZIF}-67$. A broad peak was observed in the range of $20^{\circ}$ to $40^{\circ}$ among all samples including the naked glass slide, which can be attributed to the diffraction of amorphous glass. $\mathrm{Al}_{2} \mathrm{O}_{3} / \mathrm{ZIF-}$ 67 and RuN3/Al ${ }_{2} \mathrm{O}_{3} / \mathrm{ZIF}-67$ films (Fig. $1 \mathrm{a}$ and Fig. S2a and b) all show similar XRD patterns to ZIF-67 film on glass, suggesting that the $\mathrm{ZIF}-67$ structure is retained in the films after $\mathrm{ALD}$ deposition of $\mathrm{Al}_{2} \mathrm{O}_{3}$ and $\mathrm{RuN3}$ sensitization. Note that the diffraction patterns of the ZIF-67 film on glass seem different from that of ZIF-67 crystals (Fig. S2, $\mathrm{ESI}+$ ). This can be attributed to the impact of the glass slide on the diffraction patterns as the XRD patterns of the ZIF-67 crystals are scratched off from the glass slide resemble that of ZIF-67 crystals synthesized from standard growth (Fig. S2C, ESI ${ }^{\dagger}$ ). The retention of the ZIF-67 structure in these hybrid films was further supported by the UV-Visible absorption spectra (Fig. $1 \mathrm{~b}$ and Fig. S3, ESI ${ }^{+}$), where $\mathrm{Al}_{2} \mathrm{O}_{3} / \mathrm{ZIF}-67$ and RuN3/Al $\mathrm{O}_{3} / \mathrm{ZIF}-67$ films with different thickness of $\mathrm{Al}_{2} \mathrm{O}_{3}$ all show absorption peaks centered at $585 \mathrm{~nm}$ originating from $T_{d} C O{ }^{11} d-d$ transition, consistent with that of ZIF-67. ${ }^{25}$ While RuN3 has a prominent absorption 
peak around $500 \mathrm{~nm}$ corresponding to ligand-to-metal charge transfer band (LMCT) (pink plot in Fig. 1b), it cannot be easily seen from the UV-visible absorption spectrum of RuN3/ZIF-67 due to its overlap with ZIF-67 absorption. Nevertheless, the transient absorption experiments below confirm the adsorption of RuN3 on the surface of $\mathrm{Al}_{2} \mathrm{O}_{3} / \mathrm{ZIF}-67$ film.
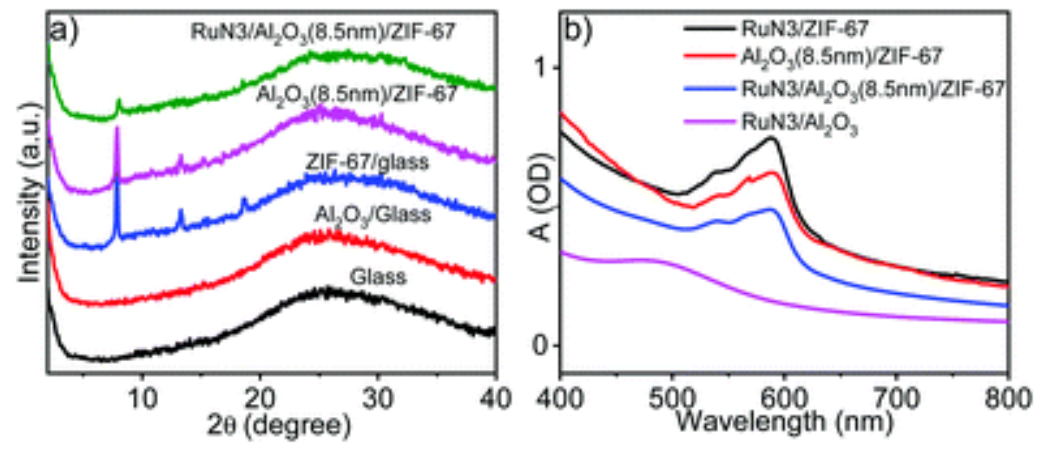

Fig. 1 (a) XRD patterns of glass, $\mathrm{Al}_{2} \mathrm{O}_{3} /$ glass, ZIF-67/glass, $\mathrm{Al}_{2} \mathrm{O}_{3}(8.5 \mathrm{~nm}) / \mathrm{ZIF}-67$ and $\mathrm{RuN3} / \mathrm{Al}_{2} \mathrm{O}_{3}(8.5 \mathrm{~nm}) / \mathrm{ZIF}-67$. (b) UV-visible absorption spectra of RuN3/ZIF-67, $\mathrm{Al}_{2} \mathrm{O}_{3}(8.5 \mathrm{~nm}) / \mathrm{ZIF}-67, \mathrm{RuN} / \mathrm{Al}_{2} \mathrm{O}_{3}(8.5 \mathrm{~nm}) / \mathrm{ZIF}-67$ and $\mathrm{RuN} 3 / \mathrm{Al}_{2} \mathrm{O}_{3}$.

Transient absorption (TA) spectroscopy is used to examine the impact of the thickness of the $\mathrm{Al}_{2} \mathrm{O}_{3}$ layer on the ENT dynamics from RuN3 to ZIF-67. Fig. 2a shows the TA spectra of RuN3/ZIF-67 following $410 \mathrm{~nm}$ excitation, which selectively excites RuN3 as ZIF-67 has negligible absorption at $410 \mathrm{~nm}$. Consistent with the previous literature result, ${ }^{29}$ immediately following the excitation, the TA spectra of RuN3/ZIF-67 show a negative ground state bleach (GSB) centered at $\sim 530 \mathrm{~nm}$ and a broad positive excited state absorption (ESA) feature at $>570 \mathrm{~nm}$, which is due to the excitation of RuN3, resulting in the depopulation of the RuN3 ground state and population of the RuN3 excited state. As the lifetime of excited singlet state of LMCT ( ${ }^{1} \mathrm{LMCT}$ ) is $<100 \mathrm{fs},{ }^{44,45}$ which is much faster than our instrument response time ( $200 \mathrm{fs})$, the ESA absorption of RuN3 can be attributed to ${ }^{3} \mathrm{LMCT}$. The GSB of RuN3 recovers and ESA decays with time simultaneously (Fig. 2b), which is accompanied by the formation of a derivative feature consisting of a negative feature centered at $585 \mathrm{~nm}$ and absorption at $605 \mathrm{~nm}$ at later time (>200 ps), consistent with the typical spectral features of the excited state of ZIF-67 corresponding to ${ }^{4} A_{2}(F)-{ }^{4} T_{1}(P)$ Co $d-d$ transition, ${ }^{17,25}$ suggesting that the excitation of RuN3 leads to the formation of excited ZIF-67. ${ }^{29}$ Moreover, the GSB recovery and ESA decay in RuN3/ZIF-67 are much faster than that of $\mathrm{RuN} 3 / \mathrm{Al}_{2} \mathrm{O}_{3}$ (Fig. 2b), where the latter is used as a model system for intrinsic ES dynamics of RuN3 on a solid surface as ENT from RuN3 to $\mathrm{Al}_{2} \mathrm{O}_{3}$ is not expected due to significantly larger band gap of $\mathrm{Al}_{2} \mathrm{O}_{3}$ than RuN3. ${ }^{46-}$ ${ }^{48}$ These results together support that ENT occurs from RuN3 $\left({ }^{3} \mathrm{LMCT}\right)$ to ZIF-67 $\left({ }^{4} \mathrm{~A}_{2}\right)$ following the excitation of RuN3, which quenches the ES of RuN3 and results in the formation of ZIF-67 ES, consistent with the previous report. ${ }^{29}$ With the presence of an $\mathrm{Al}_{2} \mathrm{O}_{3}$ layer ( $3 \mathrm{~nm}$ thickness) between RuN3 and ZIF-67 (Fig. 2c), the TA spectra of RuN3/Al ${ }_{2} \mathrm{O}_{3}(3 \mathrm{~nm}) / \mathrm{ZIF}-67$ resemble that of RuN3/ZIF-67. However, with increasing thickness of $\mathrm{Al}_{2} \mathrm{O}_{3}$, the derivative feature corresponding to ES of ZIF-67 in RuN3/Al ${ }_{2} \mathrm{O}_{3} / \mathrm{ZIF}-67$ becomes weaker and weaker (Fig. 2d, e and Fig. S4, ESIt) and can be barely seen when the thickness of $\mathrm{Al}_{2} \mathrm{O}_{3}$ is $8.5 \mathrm{~nm}$ (Fig. 2e). These results suggest that the ENT process is partially blocked by $\mathrm{Al}_{2} \mathrm{O}_{3}$ due to its inert nature, which results in decreasing ENT rate with increasing thickness of $\mathrm{Al}_{2} \mathrm{O}_{3}$. 

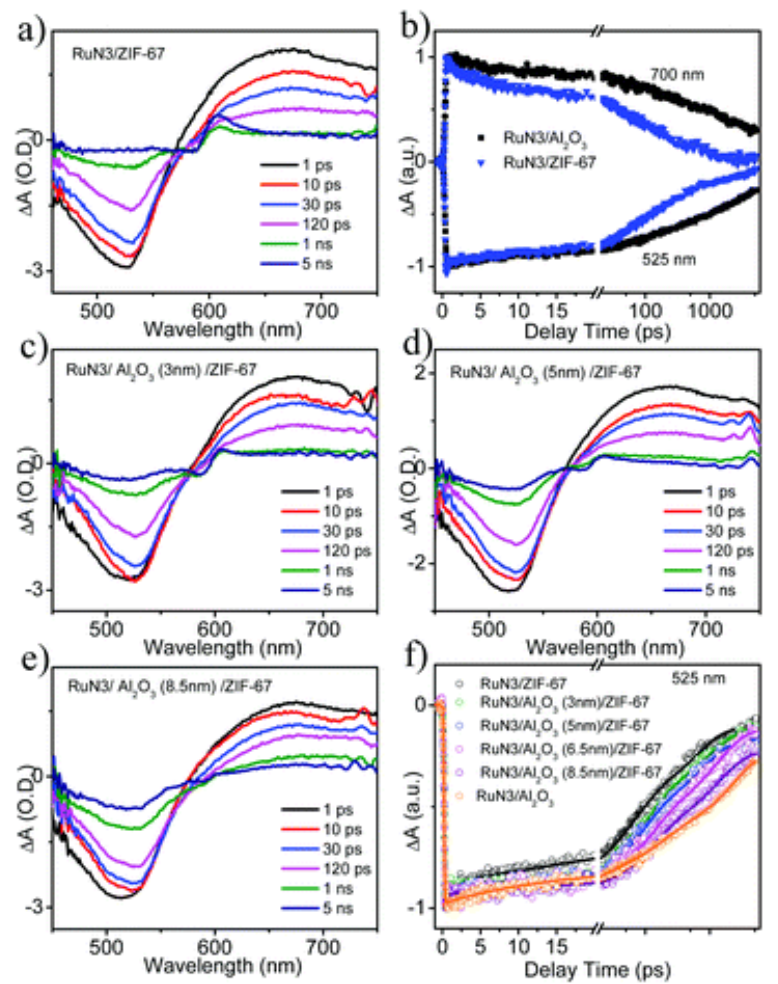

Fig. 2 Transient absorption spectra of RuN3/ZIF-67 (a), RuN3/Al $\mathrm{O}_{3}(3 \mathrm{~nm}) / \mathrm{ZIF}-67$ (c), RuN3/Al $\mathrm{O}_{3}(5 \mathrm{~nm}) / \mathrm{ZIF}-67$ (d), and RuN3/Al ${ }_{2} \mathrm{O}_{3}(8.5 \mathrm{~nm}) / \mathrm{ZIF}-67$ (e). (b) The comparison of GSB recovery and ESA decay kinetics of RuN3 on $\mathrm{ZIF}-67$ and $\mathrm{Al}_{2} \mathrm{O}_{3}$. (f) The comparison of GSB recovery kinetics of RuN3 on different substrates.

The dependence of the ENT process on $\mathrm{Al}_{2} \mathrm{O}_{3}$ thickness can be more clearly seen from the comparison of the GSB kinetics of RuN3 at $525 \mathrm{~nm}$ (Fig. 2f) or ESA of RuN3 (Fig. S5, ESI ${ }^{\dagger}$ ) among RuN3/Al $\mathrm{O}_{3} / \mathrm{ZIF}-67$ samples with different thickness of $\mathrm{Al}_{2} \mathrm{O}_{3}$. As shown in Fig. $2 \mathrm{f}$, the $\mathrm{GSB}$ recovery kinetics of $\mathrm{RuN3} / \mathrm{Al}_{2} \mathrm{O}_{3} / \mathrm{ZIF}-67$ become slower with increasing thickness of $\mathrm{Al}_{2} \mathrm{O}_{3}$, consistent with the assignment above. Since the recovery lifetime of GSB of these RuN3/Al $\mathrm{O}_{3} / \mathrm{ZIF}-67$ samples is much longer than $5 \mathrm{~ns}$, which is beyond our TA time window, the ENT time was calculated based on the half lifetime $\left(\tau_{1 / 2}\right)$, which is the time that the kinetic trace decays to half of its maximum amplitude. As listed in Table 1, $\tau_{1 / 2}$ for RuN3/Al $\mathrm{O}_{3} / \mathrm{ZIF}-67$ with $0 \mathrm{~nm}, 3 \mathrm{~nm}, 5 \mathrm{~nm}, 6.5 \mathrm{~nm}$, and $8.5 \mathrm{~nm}$ is 96 ps, 158 ps, 182 ps, 287 ps, and 528 ps, respectively. According to these half lifetimes, we estimated the ENT time according to eqn (1). $1 / \tau_{1 / 2}=1 / \tau_{0}+1 / \tau_{\mathrm{ENT}}(1) \eta=\tau_{1 / 2} / \tau_{\mathrm{ENT}}(2)$ where $\tau_{\mathrm{ENT}}$ is the ENT time from RuN3 to ZIF-67 and $\tau_{0}$ is the intrinsic ES decay time of RuN3. ENT efficiency $(\eta)$ can then be calculated according to eqn (2). The calculated ENT efficiency is also listed in Table 1. The ENT efficiency decreased almost half (from $90.6 \%$ to 46.0\%) when the thickness of the $\mathrm{Al}_{2} \mathrm{O}_{3}$ thin film increased to $8.5 \mathrm{~nm}$, indicating that the ENT efficiency in the RuN3/ZIF-67 system is sensitive to the distance between RuN3 and ZIF-67.

Table 1 The half lifetime of RuN3 GSB on different films and estimated ENT time and efficiency of RuN3/Al ${ }_{2} \mathrm{O}_{3} / \mathrm{ZIF}-67$ films

\begin{tabular}{|c|c|c|c|}
\hline & $\tau_{1 / 2}(p s)$ & $\tau_{\mathrm{ENT}}$ (ps) & $\eta_{\mathrm{ENT}}(100 \%)$ \\
\hline RuN3/ZIF-67 & 96 & 106 & 90.6 \\
\hline RuN3/Al ${ }_{2} \mathrm{O}_{3}(3 \mathrm{~nm}) / \mathrm{ZIF}-67$ & 158 & 188 & 84.0 \\
\hline $\mathrm{RuN3} / \mathrm{Al}_{2} \mathrm{O}_{3}(5 \mathrm{~nm}) / \mathrm{ZIF}-67$ & 182 & 223 & 81.6 \\
\hline $\mathrm{RuN3} / \mathrm{Al}_{2} \mathrm{O}_{3}(6.5 \mathrm{~nm}) / \mathrm{ZIF}-67$ & 287 & 406 & 70.7 \\
\hline $\mathrm{RuN3} / \mathrm{Al}_{2} \mathrm{O}_{3}(8.5 \mathrm{~nm}) / \mathrm{ZIF}-67$ & 528 & 1147 & 46.0 \\
\hline $\mathrm{RuN} 3 / \mathrm{Al}_{2} \mathrm{O}_{3}\left(\tau_{0}\right)$ & 978 & - & - \\
\hline
\end{tabular}


The theoretical Förster radius of this system was estimated by fitting the experimental data using eqn (3): ${ }^{33,39,40} \eta=1 /\left[1+\left(R / R_{0}\right)^{4}\right](3)$ where $R_{0}$ and $R$ are the Förster radius and distance between the donor and acceptor, respectively. $R_{0}$ equals $R$ when the ENT efficiency reaches $50 \%$. In the fitting process, the distance between $\mathrm{ZIF}-67$ and $\mathrm{RuN3}$ without $\mathrm{Al}_{2} \mathrm{O}_{3}(r)$ and the Förster radius $\left(R_{0}\right)$ were used as fitting parameters, where $R$ is the sum of $r$ and the thickness of the $\mathrm{Al}_{2} \mathrm{O}_{3}$ layer. As shown in Fig. 3, the experimental results can be adequately fit by the proposed model. From the best fitting, we obtained an $r$ value of $5.7 \mathrm{~nm}$ and $R_{0}$ of $14.4 \mathrm{~nm}$. The $R_{0}$ value in this system is much higher than the previously reported molecular donor/acceptor system ( $<5$ $\mathrm{nm}$ ). ${ }^{29,49,50}$ Given that a larger $R_{0}$ value results in higher FRET efficiency (eqn (3)), ${ }^{50,51}$ the much higher value in the current RuN3/ZIF-67 than the molecular systems suggests that the framework of ZIF might be beneficial for the ENT process. In addition, a larger $R_{0}$ value can typically facilitate long-range energy transfer, ${ }^{52}$ which suggests the potential of further enhancing the light absorption ability of ZIF systems through controlling the ENT process.

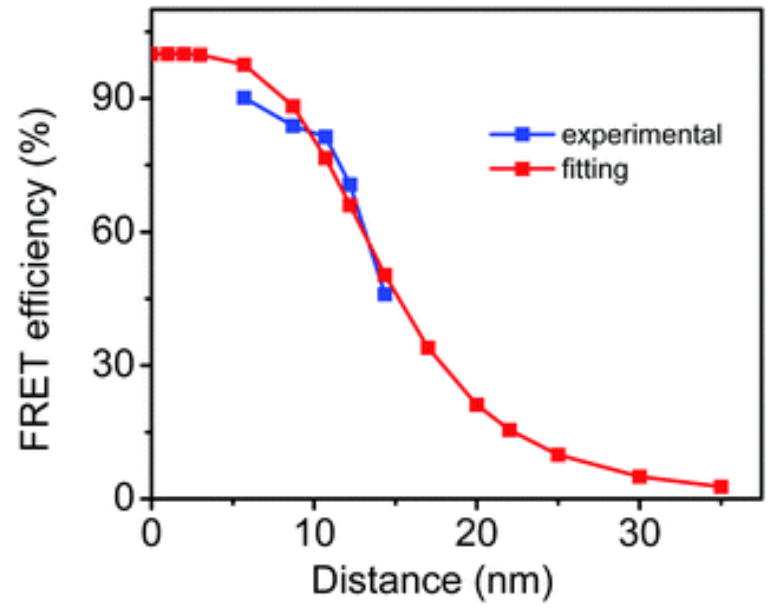

Fig. 3 The ENT efficiency as a function of distance between ZIF-67 and RuN3.

\section{Conclusion}

In summary, we report the ENT dynamics from RuN3 to ZIF-67 and the impact of distance between RuN3 (donor) and ZIF-67 (acceptor) on ENT efficiency, where the distance between the donor and acceptor was controlled by tuning the thickness of the $\mathrm{Al}_{2} \mathrm{O}_{3}$ film deposited on the surface of ZIF-67 using atomic layer deposition (ALD). Using transient absorption spectroscopy, we show that the ENT efficiency decreases with increasing thickness of the $\mathrm{Al}_{2} \mathrm{O}_{3}$ layer between $\mathrm{RuN} 3$ and $\mathrm{ZIF}-67$. According to these experimental results, the Förster radius for this system was estimated to be $14.4 \mathrm{~nm}$, which is much larger than many molecular donor/acceptor systems, suggesting the promise of enhancing the light harvesting capability of ZIFs through the ENT process. This work not only demonstrates the capability to tuning the distance of the donor and acceptor by depositing different-thickness $\mathrm{Al}_{2} \mathrm{O}_{3}$ layers using $\mathrm{ALD}$ but also provides new insight into controlling the ENT dynamics in RuN3/ZIF-67.

\section{Author contributions}

The manuscript was written through contributions of all authors. All authors have given approval to the final version of the manuscript.

\section{Conflicts of interest}

There are no conflicts to declare. 


\section{Acknowledgements}

This work was supported by National Science Foundation (DMR-1654140) and ACS-PRF (57503-DNI6). Wenhui Hu acknowledge the John J. Eisch fellowship during the 2019-2020 academic year.

\section{Notes and references}

1. R. Banerjee, A. Phan, B. Wang, C. Knobler, H. Furukawa, M. O’Keeffe and O. M. Yaghi, Science, 2008, 319, $939-943$.

2. Y. Q. Tian, Z. X. Chen, L. H. Weng, H. B. Guo, S. Gao and D. Y. Zhao, Inorg. Chem., 2004, 43, 4631 -4635.

3. H. Hayashi, A. P. Cote, H. Furukawa, M. O’Keeffe and O. M. Yaghi, Nat. Mater., 2007, 6, $501-506$.

4. S. R. Venna, J. B. Jasinski and M. A. Carreon, J. Am. Chem. Soc., 2010, 132, $18030-18033$.

5. B. Wang, A. P. Cote, H. Furukawa, M. O’Keeffe and O. M. Yaghi, Nature, 2008, 453, $207-211$.

6. Q. L. Song, S. K. Nataraj, M. V. Roussenova, J. C. Tan, D. J. Hughes, W. Li, P. Bourgoin, M. A. Alam, A. K. Cheetham, S. A. Al-Muhtaseb and E. Sivaniah, Energy Environ. Sci., 2012, 5, 8359 -8369.

7. S. Japip, H. Wang, Y. C. Xiao and T. S. Chung, J. Membr. Sci., 2014, 467, $162-174$.

8. F. Cacho-Bailo, G. Caro, M. Etxeberria-Benavides, O. Karvan, C. Tellez and J. Coronas, Chem. Commun., 2015, 51, $11283-11285$.

9. Y. Hu, Z. X. Liu, J. Xu, Y. N. Huang and Y. Song, J. Am. Chem. Soc., 2013, 135, $9287-9290$.

10. G. Lu and J. T. Hupp, J. Am. Chem. Soc., 2010, 132, $7832-7833$.

11. W. Meng, Y. Y. Wen, L. Dai, Z. X. He and L. Wang, Sens. Actuators, B, 2018, 260, $852-860$.

12. C. H. Kuo, Y. Tang, L. Y. Chou, B. T. Sneed, C. N. Brodsky, Z. P. Zhao and C. K. Tsung, J. Am. Chem. Soc., 2012, 134, $14345-14348$.

13. L. T. L. Nguyen, K. K. A. Le, H. X. Truong and N. T. S. Phan, Catal. Sci. Technol., 2012, 2, 521-528.

14. J. Zakzeski, A. Debczak, P. C. A. Bruijnincx and B. M. Weckhuysen, Appl. Catal., A, 2011, 394, 79-85.

15. H. Yang, X. W. He, F. Wang, Y. Kang and J. Zhang, J. Mater. Chem., 2012, 22, $21849-21851$.

16. J. N. Qin, S. B. Wang and X. C. Wang, Appl. Catal., B, 2017, 209, $476-482$.

17. B. Pattengale, S. Z. Yang, S. Lee and J. Huang, ACS Catal., 2017, 7, $8446-8453$.

18. S. W. Liu, F. Chen, S. T. Li, X. X. Peng and Y. Xiong, Appl. Catal., B, 2017, 211, 1-10.

19. M. Wang, J. X. Liu, C. M. Guo, X. S. Gao, C. H. Gong, Y. Wang, B. Liu, X. X. Li, G. G. Gurzadyan and L. C. Sun, J. Mater. Chem. A, 2018, 6, $4768-4775$.

20. W. M. Zhang, X. Y. Yao, S. N. Zhou, X. W. Li, L. Li, Z. Yu and L. Gu, Small, 2018, 14, 1704435.

21. N. N. Du, C. M. Wang, R. Long and Y. J. Xiong, Nano Res., 2017, 10, 3228 -3237 .

22. S. B. Wang, B. Y. Guan, X. Wang and X. W. D. Lou, J. Am. Chem. Soc., 2018, 140, $15145-15148$.

23. X. Wang, L. Yu, B. Y. Guan, S. Y. Song and X. W. Lou, Adv. Mater., 2018, 30, 1801211. 
24. A. Aijaz, J. Masa, C. Rosler, W. Xia, P. Weide, A. J. R. Botz, R. A. Fischer, W. Schuhmann and M. Muhler, Angew. Chem., Int. Ed., 2016, 55, 4087 -4091.

25. B. Pattengale, S. Z. Yang, J. Ludwig, Z. Q. Huang, X. Y. Zhang and J. Huang, J. Am. Chem. Soc., 2016, 138, $8072-8075$.

26. B. Pattengale, D. J. SantaLucia, S. Z. Yang, W. H. Hu, C. M. Liu, X. Y. Zhang, J. F. Berry and J. Huang, J. Am. Chem. Soc., 2018, 140, $11573-11576$.

27. B. Pattengale and J. Huang, Phys. Chem. Chem. Phys., 2018, 20, $14884-14888$.

28. H. Kato and K. Akimoto, J. Am. Chem. Soc., 1974, 96, $1351-1357$.

29. S. Z. Yang, B. Pattengale, E. L. Kovrigin and J. Huang, ACS Energy Lett., 2017, 2, 75 -80.

30. Y. X. Zhou, W. H. Hu, S. Z. Yang and J. Huang, Phys. Chem. Chem. Phys., 2020, 22, $3849-3854$.

31. R. S. Swathi and K. L. Sebastian, J. Chem. Sci., 2009, 121, 777 -787.

32. R. Narayanan, M. Deepa and A. K. Srivastava, J. Mater. Chem. A, 2013, 1, 3907 -3918.

33. H. T. Zhou, C. B. Qin, R. Y. Chen, W. J. Zhou, G. F. Zhang, Y. Gao, L. T. Xiao and S. T. Jia, J. Phys. Chem. Lett., 2019, 10, $2849-2856$.

34. R. E. Dale and J. Eisinger, Biopolymers, 1974, 13, $1573-1605$.

35. B. Albinsson, M. P. Eng, K. Pettersson and M. U. Winters, Phys. Chem. Chem. Phys., 2007, 9, 5847 5864.

36. C. R. Sabanayagam, J. S. Eid and A. Meller, J. Chem. Phys., 2005, 122, 061103.

37. A. A. Deniz, M. Dahan, J. R. Grunwell, T. J. Ha, A. E. Faulhaber, D. S. Chemla, S. Weiss and P. G. Schultz, Proc. Natl. Acad. Sci. U. S. A., 1999, 96, $3670-3675$.

38. R. B. Sekar and A. Periasamy, J. Cell Biol., 2003, 160, $629-633$.

39. F. Federspiel, G. Froehlicher, M. Nasilowski, S. Pedetti, A. Mahmood, B. Doudin, S. Park, J. O. Lee, D. Halley, B. Dubertret, P. Gilliot and S. Berciaud, Nano Lett., 2015, 15, $1252-1258$.

40. R. S. Swathi and K. L. Sebastian, J. Chem. Phys., 2009, 130, 086101.

41. T. Park, H. Kim, M. Leem, W. Ahn, S. Choi, J. Kim, J. Uh, K. Kwon, S. J. Jeong, S. Park, Y. Kim and H. Kim, RSC Adv., 2017, 7, $884-889$.

42. V. Vandalon and W. Kessels, Langmuir, 2019, 35, $10374-10382$.

43. O. M. E. Ylivaara, X. W. Liu, L. Kilpi, J. Lyytinen, D. Schneider, M. Laitinen, J. Julin, S. Ali, S. Sintonen, M. Berdova, E. Haimi, T. Sajavaara, H. Ronkainen, H. Lipsanen, J. Koskinen, S. P. Hannula and R. L. Puurunen, Thin Solid Films, 2014, 552, $124-135$.

44. J. Kallioinen, G. Benko, V. Sundstrom, J. E. I. Korppi-Tommola and A. P. Yartsev, J. Phys. Chem. B, 2002, 106, $4396-4404$.

45. N. H. Damrauer, G. Cerullo, A. Yeh, T. R. Boussie, C. V. Shank and J. K. McCusker, Science, 1997, 275, 54 -57 . 
46. J. B. Asbury, R. J. Ellingson, H. N. Ghosh, S. Ferrere, A. J. Nozik and T. Q. Lian, J. Phys. Chem. B, 1999, 103, $3110-3119$.

47. O. Flender, M. Scholz, J. R. Klein, K. Oum and T. Lenzer, Phys. Chem. Chem. Phys., 2016, 18, $26010-$ 26019.

48. M. Fakis, P. Hrobarik, O. Yushchenko, I. Sigmundova, M. Koch, A. Rosspeintner, E. Stathatos and E. Vauthey, J. Phys. Chem. C, 2014, 118, $28509-28519$.

49. M. Rehorek, N. A. Dencher and M. P. Heyn, Biochemistry, 1985, 24, 5980 -5988.

50. G. Ramos-Ortiz, Y. Oki, B. Domercq and B. Kippelen, Phys. Chem. Chem. Phys., 2002, 4, 4109 -4114.

51. B. R. Lee, W. Lee, T. L. Nguyen, J. S. Park, J. S. Kim, J. Y. Kim, H. Y. Woo and M. H. Song, ACS Appl. Mater. Interfaces, 2013, 5, $5690-5695$.

52. X. Zhang, C. A. Marocico, M. Lunz, V. A. Gerard, Y. K. Gun’ko, V. Lesnyak, N. Gaponik, A. S. Susha, A. L. Rogach and A. L. Bradley, ACS Nano, 2014, 8, $1273-1283$. 